\title{
Konsep Pendidikan Budi Pekerti Perspektif Ki Hadjar Dewantara
}

\author{
Zainuddin \\ Institut Agama Islam Nazhatut Thullab Sampang \\ Email: Zainuddinsampang1@gmail.com
}

\begin{abstract}
Abstrak:
Dewasa ini sistem pendidikan telah kehilangan visi sejatinya, kebanyakan lembaga pendidikan kini cenderung mengusung visi pragmatis, yaitu mencetak lulusan yang siap kerja. Karena pada hakikatnya tujuan pendidikan bukan hanya mempersiapkan generasi yang kompeten dan berdaya saing tinggi dalam memperoleh pekerjaan. Namun harus dibekali dengan nilai-nilai budi pekerti luhur. Pendidikan hanya berorientasi pada kehidupan duniawi sehingga aspek-aspek spiritual keagamaan kurang diperhatikan. Dari fenomena diatas menunjukkan bahwa saat ini sudah terjadi moral crisis yang harus segera dikembalikan kepada ruh-ruh pendidikan budi pekerti yang luhur. Hal ini sejalan dengan apa yang telah diperjuangkan oleh Ki Hajar Dewantara pada masanya tentang konsep pendidikan budi pekerti. Dalam penelitian ini, penulis menformulasikan fokus penelitian terhadap beberapa hal diantaranya: Bagaimana penerapan pemikiran konsep pendidikan budi pekerti Ki Hadjar Dewantar di Indonesia, dan bagaimana hubungan konsep pendidikan budi pekeri Ki Hadjar Dewantara dengan Pendidikan Agama Islam? Penelitian ini menggunakan pendekatan historis, dan pendekatan filosofis, sedangkan jenis penelitiannya adalah studi pustaka (library research). Teknik pengumpulan data yang digunakan adalah studi kepustakaan atau dokumentasi. Dalam Tehnik Analisa Data, penulis menggunakan metode deduktif dan induktif. Hasil analisis penulis terhadap pemikiran Ki Hajar Dewantara bahwa pendidikan budi pekerti dan pembentukan karakter anak bangsa menjadi menjadi tanggung sekolah, keluarga, dan lingkungan masyrakat. Sehingga melahirkan kesimpulan bahwa penyelenggaraan pendidikan jangan terjebak pada pencapaian target sempit, yang hanya melakukan transfer of knowledge melainkan perlu dengan sengaja (by design) mengupayakan terjadinya transformasi nilai budi luhur dalam membentuk karakter anak bangsa. Dan dalam hal ini Pendidikan Agama Islam memiliki andil besar dalam menanamkan nilai-nilai budi pekerti luhur terhadap peserta didik.
\end{abstract}

Kata Kunci: Konsep, Pendidikan, Budi Pekerti

\begin{abstract}
Abstrak:
Today the education system has lost its true vision, most educational institutions now tend to carry a pragmatic vision of getting graduates ready for work. Because in essence the goal of education is not only to prepare a competent and highly competitive generation in getting a job but also they must be equipped with noble character values. Education is oriented only in worldly life so that spiritual aspects are noticed. From the above phenomenon shows that now there is a moral crisis that must be immediately returned to the spirit of noble character education. This is relevant with Ki Hajar Dewantara's opinion has championed in his time about the concept of moral education. In this study, the writer formulates the focus of research on several things including: How the application of Ki Hadjar Dewantara's concept of education character in Indonesia, and how the relationship between Ki Hadjar Dewantara's concepts of education character with Islamic Religious Education? This study uses a historical approach, and philosophical approach, while the type of research is library research. Data collection techniques used is literature study or documentation. In Data Analysis Techniques, the writer uses deductive and inductive methods. The results of the
\end{abstract}


writer's analysis of Ki Hajar Dewantara's thinking that character education and character formation of the nation become the responsibility of school, family, and community environment. So that the conclusion that the implementation of education should not be trapped in the achievement of narrow targets, which only transfer of knowledge but need to deliberately (by design) seeks the transformation of virtuous values in shaping the character of the nation. And in this case Islamic Religious Education has a big contribution in instilling the values of noble character towards the learner.

\section{Keywords: Consepts, Educations, and Characters}

\section{Pendahuluan}

Dewasa ini sistem pendidikan telah kehilangan visi sejatinya, kebanyakan lembaga pendidikan kini cenderung mengusung visi pragmatis, yaitu mencetak lulusan yang siap kerja. Karena pada hakikatnya tujuan pendidikan bukan hanya mempersiapkan generasi yang kompeten dan berdaya saing tinggi dalam memperoleh pekerjaan. Namun harus dibekali dengan nilai-nilai budi pekerti luhur. Pendidikan hanya berorientasi pada kehidupan duniawi sehingga aspek-aspek spiritual keagamaan kurang diperhatikan. Lembaga-lembaga pendidikan hanya mampu menghasilkan individu-individu yang cerdas dan terampil tetapi ruhaninya kosong. Kecerdasan dan keterampilan mereka yang tinggi tidak diimbangi dengan akhlaknya, khususnya dalam konteks sosial keagamaan.

Krisis spiritual dalam era modern yang menimpa anak indonesia, merupakan cerminan dari keringnya nilai-nilai spiritual dan moral yang menjadi elemen dasar bagi seseorang untuk menata kehidupan dengan kejujuran dan ketulusan. Anak Indonesia seolah telah dikuasai oleh impian dan kemilau kehidupan duniawi yang sesat sehingga tidak menempatkan nilai-nilai spirtual sebagai tujuan agung dalam kehidupan. Padahal, nilai-nilai spiritual menjadi landasan fundamental bagi tegaknya spirit keimanan yang dipadukan dengan kesalehan sosial antara sesama. Para pakar pendidikan Islam telah sepakat bahwa tujuan dari pendidikan serta pengajaran bukanlah memenuhi otak anak didik dengan segala macam ilmu yang belum mereka ketahui, melainkan untuk mendidik akhlak dan jiwa mereka, menanamkan rasa keutamaan (fadilah), membiasakan mereka dengan kesopanan yang tinggi, mempersiapkan mereka untuk suatu kehidupan yang suci seluruhnya dengan penuh keikhlasan, kejujuran dan mampu meningkatkan kematangan serta integritas kesempurnaan pribadi dari setiap anak Indonesia. ${ }^{1}$

Institusi pendidikan yang terdiri dari sekolah/madrasah, keluarga dan lingkungan sosial, harus menjadi teladan atau modelling bagi proses pembelajaran dan pendidikan peserta didik, hal tersebut disebabkan praktik pendidikan disetiap jenjangnya bukan sekedar pengembangan nalar peserta didik, tetapi juga adalah pembentukan akhlak alkarimah dan akal yang berbudi. Pendidikan akhlak alkarimah adalah termasuk pembinaan watak-karakter siswa bahkan sampai dengan proses pendidikan di perguruan tinggi, sejak lama tidak mendapat perhatian serius dalam praktek pendidikan di Indonesia, kalaupun terdapat jam mata pelajaran agama dan akhlak hanyalah sebagai pengetahuan bukan untuk diamalkan dengan baik. ${ }^{2}$

Selain itu pendidikan juga merupakan sarana yang sangat dibutuhkan oleh manusia, sebab pendidikan meliputi keseluruhan tingkah laku manusia yang dilakukan demi memperoleh keseimbangan, pertahanan, dan peningkatan hidup, artinya manusia dapat menjadi manusia yang baik dan buruk melalui proses pendidikan budi pekerti. Sedangkan

\footnotetext{
${ }^{1}$ Muhammad Takdir Ilahi, Gagalnya Pendidikan Karakter: Analisis dan Solusi Pengendalian Karakter Emas Anak Didik, (Yogyakarta: Ar Ruzz Media 2014), hlm., 42-43.

${ }^{2}$ Pupuh Fathorrohman dkk, Pengembangan Pendidikan Karakter, (Bandung : PT Refika Aditama, 2013), hlm., 1.
} 
pendidikan budi pekerti merupakan program pengajaran di sekolah yang bertujuan mengembangkan watak atau tabiat siswa dengan cara menghayati nilai-nilai dan keyakinan masyarakat sebagai kekuatan moral dalam hubungannya melalui kejujuran, dapat dipercaya, disiplin, dan kerja sama yang menekankan ranah afektif tanpa meninggalkan ranah kognitif dan ranah psikomotorik. ${ }^{3}$ Sementara itu, Ki Hadjar Dewantara mengatakan bahwa pendidikan ialah usaha kebudayaan yang bermaksud memberi bimbingan dalam hidup tumbuhnya jiwa raga anak agar dalam kodrat pribadinya serta pengaruh lingkungannya, mereka memperoleh kemajuan lahir batin menuju ke arah adab kemanusiaan. Sementara yang di maksud adab kemanusiaan adalah tingkat tertinggi yang dapat dicapai oleh manusia yang berkembang selama hidupnya. Artinya, dalam upaya mencapai kepribadian seseorang atau karakter seseorang, adab kemanusiaan adalah tingkat yang tertinggi. ${ }^{4}$

Saat ini wajah bangsa masih coreng-moreng dengan berbagai peristiwa, seperti kasus korupsi yang sudah menjadi tradisi para pemegang kekuasaan dan pembuat kebijakan, baik di eksekutif, legislatif maupun yudikatif, tawuran pelajar yang sudah membudaya dalam demokrasi kanibal, kerusakan berdasarkan SARA dan perbedaan aliran serta mazhab yang mengorbankan banyak anak bangsa, rakyat yang termarginalkan di riuh rendah hiruk pikuk politik yang menunjukkan aksi kemiskinannya di keramaian kota, kondisi alam kian lesu dan pucat akibat penebangan hutan dan pencemaran lingkungan, dan penguasa dengan leluasa menunjukkan perilaku minus keteladanan di hadapan rakyatnya. Begitulah kenyataannya. Bangsa ini lemah dalam karakter. Kerakter bangsa adalah sekumpulan karakter individu di sebuah negara. Sebuah bangsa melalui pemimpinnya dapat membentuk karakter individu yang mempuni, yang akan membawa bangsa dalam mewujudkan kesejahteraan sebagai cita-cita paling ideal bangsa ini. ${ }^{5}$

Oleh karena itu dengan adanya pendidikan budi pekerti tiap-tiap manusia berdiri sebagai manusia merdeka (berpribadi), yang dapat memerintah atau menguasai diri sendiri (mandiri). Inilah manusia yang beradab dan itulah maksud dan tujuan pendidikan dalam garis besarnya. ${ }^{6}$ Kita ketahui, bangsa-bangsa yang memiliki karakter (budi pekerti) tangguh lazimnya tumbuh berkembang makin maju dan sejahtera.

Peneliti sangat tertarik untuk meneliti pemikiran Ki Hadjar Dewantara tentang pendidikan budi pekerti. Karena dengan adanya pendidikan budi pekerti diharapkan mampu mengatasi permasalahan yang tidak sesuai dengan nilai dan norma yang berlaku di masyarakat. Untuk itu penulis mencoba menguraikan konsep pendidikan Ki Hadjar Dewantara tentang budi pekerti perspektif. Penulis tertarik untuk mengangkatnya sebagai bahan penulisan skripsi yang berjudul "Konsep Pendidikan Budi pekerti Perspektif Ki Hadjar Dewantara".

\section{Metode Penelitian \\ Pendekatan Penelitian}

Penelitian ini termasuk katagori karya ilmiah yang menggunakan pendekatan historis, dan pendekatan filosofis. Pertama pendekatan historis yaitu mengkaji biografi, karya serta corak pemikiran (tokoh pemikiran) dilihat dari kaca mata sejarah hidupnya yakni dilihat dari kondisi sosial, politik dan budaya pada masa itu, dikaji secara kritis dan

\footnotetext{
${ }^{3}$ Nurul Zuriah, Pendidikan Moral dan Budi Pekerti Dalam Prespektif Perubahan, (Jakarta :PT Bumi Aksara, 2007), hlm., 19-20.

${ }^{4}$ Rulam Ahmadi, hlm., 169-170.

${ }^{5}$ Anas Salahudin,, irwanto, Pendidikan Karakter (pendidikan berbasis agama dan budaya bangsa), (Bandung: Cv Pustaka Setia, 2013),hlm., 30.

${ }^{6}$ Ki Hadjar Dewantara, Bagian Pertama Pendidikan,(Yogyakarta: Majelis Luhur Persatuan Taman Siswa, 1977), hlm., 25.
} 
mendalam untuk melihat keadaan, perkembangan dan pengalaman masa lalu, berdasarkan urutan waktu analisa yang berangkat dari sejarah. Kedua yaitu pendekatan filosofi yakni pendekatan yang mendasari konsep-konsep pemikiran Ki Hadjar Dewantara mengenai pendidikan budi pekerti secara filsafat dan epistemologi.

\section{Jenis penelitian}

Jenis penelitian ini adalah studi pustaka (library research), yaitu penelitian dalam bentuk kajian teoritis terhadap pemikiran karya seseorang dalam bentuk dokumentasi.

\section{Sumber Data}

Didalam penelitian ini, penulis menggunakan dua sumber data, yaitu: pertama, Data Primer adalah sumber data yang langsung memberikan data yang berhubungan dengan judul penelitian. Kedua, Data Sekunder sebagai sumber penunjang atau pendukung dalam penelitian ini adalah buku-buku, jurnal, makalah, artikel, dan lain-lain.

\section{Teknik Pengumpulan Data}

Teknik pengumpulan data yang digunakan adalah studi kepustakaan atau dokumentasi yang mengkaji dan menela'ah berbagai buku, tulisan artikel, jurnal ataupun majalah yang mempunyai relevansi dengan tema pokok dalam pembahasan skripsi ini.

\section{Teknik Analisis Data}

Teknik analisis data yang digunakan penulis dalam penulisan skripsi ini adalah:

\section{Deduktif}

Metode deduktif adalah metode berfikir yang berdasarkan pada pengetahuan umum dimana kita hendak menilai suatu kejadian yang khusus. Metode ini digunakan untuk menjelaskan konsep pendidikan budi pekerti yang merupakan salah satu sistem pendidikan karakter di Indonesia.

\section{Induktif}

Metode Induktif adalah metode berfikir yang berangkat dari fakta-fakta peristiwa khusus dan konkret, kemudian ditarik generalisasi-generalisasi yang bersifat umum. Metode ini digunakan untuk membahas sejumlah data tentang konsep budi pekerti menurut Ki hajar dewantara guna di tarik kesimpulan di dalamnya dan dicari relevansinya dengan dunia pendidikan nasional pada masa kini. ${ }^{7}$

\section{Pembahasan dan Hasil Penelitian Pendidikan}

Kata pendidikan merupakan bentuk nomina dari kata dasar 'didik' yang mendapat awalan 'pe' dan akhiran 'an'. Dalam Kamus Besar Bahasa Indonesia, pendidikan diartikan sebagai proses penghubungan sikap dan tata laku seseorang atau kelompok orang dalam usaha mendewasakan manusia melalui upaya pengajaran dan pelatihan; proses, cara, perbuatan mendidik. ${ }^{8}$ Kata pendidikan dan pengajaran itu seringkali dipakai bersamasama.

Menurut Ki Hadjar pengertian pendidikan secara umum adalah tuntunan didalam hidup tumbuhnya anak-anak. Maksudnya pendidikan yaitu menuntun segala kekuatan kodrat yang ada pada anak-anak itu, agar mereka sebagai manusia dan sebagai anggota masyarakat dapatlah mencapai keselamatan dan kebahagiaan yang setinggi-tingginya. ${ }^{9}$ Tidak hanya itu Ki Hadjar juga berpendapat bahwa pendidikan adalah daya upaya untuk memajukan bertumbuhnya budi pekerti (kekuatan batin, karakter), pikiran (intellect) dan

\footnotetext{
${ }^{7}$ Sutrisno Hadi , Metodologi Research, (Yogyakarta: Yayasan Penerbitan Fakultas Psikologi UGM Jogjakarta, 1987).hlm, 42

${ }^{8} \mathrm{KBBI}$ (Kamus Besar Bahasa Indonesia) versi offline, edeisi III, data mengacu pada http://pusatbahasa.diknas.go.id/kbbi/ diakses tanggal 26 Februari 2017.

${ }^{9}$ Ki Hadjar Dewantara, Bagian Pertama Pendidikan,(Yogyakarta: Majelis Luhur Persatuan Taman Siswa, 1977) , hlm., 20.
} 
tubuh anak. ${ }^{10}$ Dalam pelaksanaan pendidikan, Ki Hadjar Dewantara menggunakan "Sistem Among" sebagai perwujudan konsepsinya dalam menempatkan anak sebagai sentral proses pendidikan. Dalam Sistem Among, terdapat Trilogi kepemimpinan Ki Hadjar Dewantara dimana setiap pamong sebagai pemimpin dalam proses pendidikan diwajibkan menerapkan sikap trilogi tersebut. ${ }^{11}$

Yang pertama, Ing ngarsa sung tuladha. Berarti didepan memberikan teladan. Kedua, Ing madya mangun karsa. Berarti di tengah-tengah memberi semangat. Ketiga, Tutwuri handayani. Di belakang memberi dukungan dan dorongan.

\section{Pengertian Budi Pekerti}

Budi pekerti, atau watak, yaitu bulatnya jiwa manusia, yang dalam bahasa asing disebut "karakter". Orang yang telah mempunyai kecerdasan budi pekerti senantiasa memikirkan, merasakan serta selalui memakai ukuran, timbangan, dan dasar-dasar yang pasti dan tetap. Itulah sebabnya tiap-tiap orang itu dapat kita kenal wataknya dengan pasti, karena watak atau budi pekerti itu memang bersifat tetap dan pasti buat satu-satunya manusia, sehingga dapat dibedakan orang yang satu dari pada yang lain. Budi pekerti, watak atau karakter, itulah bersatunya gerak pikiran, perasaan, dan kehendak atau kemauan, yang menimbulkan tenaga. Jadi budi pekerti itu sifatnya jiwa manusia, mulai angan-angan hingga terjelma sebagai tenaga. ${ }^{12}$

Budi pekerti menurut Ki Hadjar bukan sekedar konsep teoritis sebagaimana yang dipahami masyarakat pada umumnya. Pengajaran budi pekerti juga bukan berarti mengajar teori tentang baik buruk, benar salah dan seterusnya; bukan pula pengajaran dalam bentuk pemberian kuliah atau ceramah tentang hidup kejiwaan atau peri-keadaban manusia dan atau keharusan memberi keterangan-keterangan tentang budi pekerti secara luas dan mendalam. Pengajaran budi pekerti, tegas Ki Hadjar, diterapkan untuk menyokong perkembangan hidup anak-anak, menuju kearah peradaban dalam sifatnya yang umum. Seperti mengajarkan anak bagaimana duduk yang baik, tidak berteriak-teriak agar tidak mengganggu orang lain, bersih badan dan pakaian, hormat terhadap ibu bapak dan orang lain, suka menolong dan lain sebagainya. ${ }^{13}$

\section{Pengertian Budi Pekerti Secara Operasional}

Budi pekerti, watak, atau karakter, bermakna bersatunya gerak pikiran, perasaan, dan kehendak atau kemauan, yang menimbulkan tenaga. Makna "Budi" berarti pikiran, perasaan, kemauan, sedang "Pekerti" artinya "tenaga". Jadi "Budi Pekerti" itu sifatnya jiwa manusia, mulai angan-angan hingga terjelma sebagai tenaga. Pendidikan budi pekerti secara oprasional adalah upaya untuk membekali peserta didik melalui bimbingan, pengajaran, dan latihan selama pertumbuhan dan perkembangan dirinya sebagai bekal masa depannya agar memiliki hati nurani yang bersih, berperangai baik, serta menjaga kesusilaan dalam melaksanakan kewajiban terhadap Tuhan dan sesama makhluk. Dengan demikian, terbentuklah pribadi seutuhnya yang tercermin pada perilaku yang berupa ucapan, perbuatan, sikap, pikiran, perasaan, kerja dan hasil karya berdasarkan nilai-nilai agama serta norma dan moral luhur bangsa. ${ }^{14}$

\footnotetext{
${ }^{10}$ Muchlas Samani dan Hariyanto, Konsep dan Model Pendidikan Karakter (Bandung: PT Remaja Rosdakarya, 2011), hlm., 33.

${ }^{11}$ Rulam Ahmadi, hlm., 170.

${ }^{12}$ Ki Hadjar, hlm., 24-25.

${ }^{13}$ Abuddin Nata, Tokoh-tokoh Pembaruan Pendidikan Islam di Indonesia, (Jakarta: Raja Grafindo Persada, 2005), hlm., 25.

${ }^{14}$ Nurul Zuriyah, Pendidikan Moral dan Budi Pekerti Dalam Prespektif Perubahan, (Jakarta:PT Bumi Aksara,2007), hlm., 19-20.
} 


\section{Tujuan Pendidikan Budi Pekerti}

Pendidikan budi pekerti merupakan program pengajaran di sekolah yang bertujuan mengembangkan watak atau tabiat siswa dengan cara menghayati nila-inilai dan keyakinan masyarakat sebagai kekuatan moral dalam kehidupannya melalui kejujuran, dapat dipercaya, disiplin, dan kerja sama yang menekankan ranah afektif (perasaan dan sikap) tanpa meninggalkan ranah kognitif (berpikir rasional) dan ranah psikomotorik (keterampilan, terampil mengolah data, mengemukakan pendapat, dan kerja sama). Tidak hanya itu pendidikan budi pekerti juga bertujuan untuk meningkatkan mutu proses dan hasil pendidikan yang mengarah pada pembentukan karakter dan akhlak mulia peserta didik secara utuh, terpadu, dan seimbang, sesuai dengan standar kompetensi lulusan pada satuan pendidikan. Melalui pendidikan budi pekerti peserta didik diharapkan mampu secara mandiri meningkatkan dan menggunakan pengetahuannya, mengkaji dan menginternalisasikan serta mempersonalisasikan nilai-nilai budi pekerti dan akhlak mulia sehingga terwujud dalam perilaku sehari-hari. ${ }^{15}$

\section{Analisis Pemikiran Ki Hajar Dewantara Tentang Pendidikan Budi Pekerti}

Bangsa Indonesia yang telah mendeklarasikan kemerdekaannya sejak 17 Agustus 1945 memiliki kondisi yang amat unik dilihat dari perkembangan pendidikannya saat ini. Kurang lebih 71 tahun rakyat Indonesia menjalani kehidupan berbangsa dan bernegara secara merdeka. Namun sangat ironis ketika kondisi bangsa sudah terkontaminasi oleh moral generasi muda yang rusak. Berbagi macam tindak kriminal, pelecehan seksual, kekerasan, seks bebas, narkoba, dan lain sebagainya sudah bukan hal tabu dikalangan generasi muda Indonesia. Jika hal ini dibiarkan, maka tidak menutup kemugkinan bangsa Indonesia akan mengalami degradasi di berbabagai sektor. ${ }^{16}$ Fenomena ini seakan menunjukkan bahwa pendidikan berkarakter menjadi kebutuhan mutlak bagi bangsa Indonesia. Sehingga nantinya tidak ada lagi generasi muda yang hanya pintar tapi tidak benar.

Seperti yang diuraikan oleh Ki Hajar Dewantara bahwa Budi pekerti, atau watak, yaitu bulatnya jiwa manusia, yang dalam bahasa asing disebut "karakter". Orang yang telah mempunyai kecerdasan budi pekerti senantiasa memikirkan, merasakan serta selalui memakai ukuran, timbangan, dan dasar-dasar yang pasti dan tetap. Itulah sebabnya tiaptiap orang itu dapat kita kenal wataknya dengan pasti, karena watak atau budi pekerti itu memang bersifat tetap dan pasti buat satu-satunya manusia, sehingga dapat dibedakan orang yang satu dari pada yang lain. Budi pekerti, watak atau karakter, itulah bersatunya gerak pikiran, perasaan, dan kehendak atau kemauan, yang menimbulkan tenaga. Jadi budi pekerti itu sifatnya jiwa manusia, mulai angan-angan hingga terjelma sebagai tenaga. ${ }^{17}$

Menurut Kamus Lengkap Bahasa Indonesia, karakter adalah sifat-sifat kejiwaan, akhlak, atau budi pekerti yang membedakan seseorang dari yang lainnya, tabiat, watak. Karakter merupakan kepribadian yang mencakup beberapa aspek yang luas, baik itu kualitas atau kekuatan mental seseorang, tercakup didalamnya juga akhlak atau juga budi pekerti dan ini merupakan kepribadian khusus yang dimiliki oleh individu. ${ }^{18}$

\footnotetext{
${ }^{15}$ Mulyasa. Manajemen Pendidikan Karakter, (Jakarta: PT Bumi askara,2014), hlm., 9.

${ }^{16}$ Tri Sukitman, Bimbingan Konseling Berbasis Pendidikan Karakter, (Yogyakarta: DIVA Press, 2015), hlm., 59-60.

${ }^{17} \mathrm{Ki}$ Hadjar, hlm.24-25

${ }^{18}$ Evi Hanifah, Istilah Nilai, karakter, Akhlak, Moral, Budi Pekerti, dan Etika, diakses dari https://hanivie.wordpress.com/2013/05/17/istilah-nilai-karakter-akhak-moral-budi-pekerti-dan-etika/ pada tanggal 07 Mei 2017 pukul 22.23
} 
Meski demikian, dalam pendidikan budi pekerti, pembentukan karakter anak bangsa menjadi kewajiban. Dalam penerapannya di Indonesia dapat dilakukan dengan beberapa hal diantaranya: ${ }^{19}$

1. Menerapkan pendekatan modeling dan exemplary

2. Menjelaskan atau mengklarifikasi secara kontinu tentang nilai kebaikan.

3. Menerapkan pendidikan berdasarkan karakter (character based education).

Sebenarnya, perkembangan moral melibatkan tiga komponen dasar. Kohlberg menyebutkan ketiga komponen itu ialah moral behavior (yaitu bagaimana seseorang bertingkah laku), moral emotion (yaitu apa yang dirasakan oleh seseorang setelah melakukan sesuatu), moral judgement (alasan yang dipakai orang dalam mengambil keputusan). Kohlberg membagi perkembangan moral seseorang dalam tiga tingkat, yaitu tingkat prakonvesional, tingkat konvesional, dan tingkat pasca konvesional. Dari ketiga tingkat tersebut Kohlberg membagi menjadi enam tahap yaitu sebagai berikut. 20

1. Orientasi pada hukuman dan ketaatan (Punishment-obedience orientation)

2. Tahap orientasi hedonis (Instrumental-relativist orientation)

3. Orientas anak manis (Interpersonal concordance orientation) Maintaining)

4. Orientasi terhadap hukum dan ketertiban (Law and Order orientation/Social-order

5. Orientasi kontrak sosial legalitas (Social contract orientation)

6. Orientasi suara hati (Universal ethical principle orientation)

Tahap-tahap perkembangan moral menurut Kohlberg berkaitan dengan penalaran (moral thinking) bukan tindakan (moral action). Orang yang mempunyai penalaran moral tingkat tinggi belum tentu berperilaku demikian pula, sehingga korelasi yang sempurna dari penalaran moral dan tingkah laku moral tidak dapat diharapkan. Hasil penelitian Kohlberg menemukan bahwa factor intelegensi, status sosial ekonomi, kelompok sosial dan factor pribadi dianggap sebagai hal-hal yang mempengaruhi perkembangan moral. Di samping itu faktor situasi, motivasi, dan emosi juga dianggap mempengaruhi perilaku individu, sehingga sering terjadi ketidaksesuaian antara moral judgement dan moral behavior. ${ }^{21}$

Hal tersebut diatas senada dengan yang diuraikan oleh Ki Hajar Dewantara bahwa setiap manusia memiliki potensi berbeda yang merupakan bawaan sejak lahir. Hanya dengan pendidikanlah seluruh potensi yang dimiliki manusia berkembang sehingga menjadi manusia yang seuutuhnya. Maksud dari apa yang disampaikan oleh Ki Hajar Dewantara ini bahwa pendidikan harus diarahkan pada pengolahan empat domain, diantaranya: olah pikir, olah rasa, olah raga, dan olah hati. ${ }^{22}$

Proses pendidikan karakter diajarkan untuk mengupayakan keberhasilan dalam pendidikan karakter, ada beberapa proses pendidikan karakter yang perlu diterapkan di Indonesia, yaitu:

a. Knowing the good ( $t a^{\prime} l i m$ ), yaitu tahap memberikan pemahaman tentang nilai-nilai agama/ akhlak melalui dimensi akal, rasio dan logika dalam setiap bidang studi

b. Loving the good (tarbiyah), yaitu tahap menumbuhkan rasa cinta dan rasa butuh terhadap nilai-nilai kebaikan, melalui dimensi emosional. Hati, dan jiwa.

c. Doing the good (taqwim), yaitu tahap mempraktekkan nilai-nilai kebaikan, melalui dimensi perilaku dan amaliyah. ${ }^{23}$

\footnotetext{
${ }^{19}$ Ar Rozi, 70.

${ }^{20}$ Zuriah, Pendidikan Moral, hlm., 35.

${ }^{21}$ Ar Rozi, 62.

${ }^{22}$ Muhammad Yaumi, Pendidikan Karakter, Landasan, Pilar, dan Implimentasi, (Jakarta: PrenadaMedia Group, 2014), hlm., 6.

${ }^{23}$ Anas Salahuddin dan Irwanto Alkrienchiehie, Pendidikan Karakter, Pendidikan Berbasis Agama dan

Budaya Bangsa, (Bandung: Pustaka Setia, 2013)., hlm, 71.
} 
Berdasarkan keinginan dan dambaan orang tua dan para pendidik pada umumnya manusia seperti apa yang mereka inginkan terjadi dalam diri anak didik. Yang jelas mereka menginginkan bahwa anak didik menjadi manusia yang utuh, yang berkembang bukan hanya ilmu pengetahuan tetapi juga sikap dan nilai kemanusiaan yang lain. Lebih jelasnya manusia macam apa yang didambakan oleh pendidikan budi pekerti, diantaranya:24

1. Manusia sebagai makhluk yang berakal budi

2. Manusia sebagai pribadi

3. Manusia adalah makhluk sosial

4. Manusia sebagai makhluk yang berbudaya

Sebenarnya, pendidikan budi pekerti telah dipikirkan oleh para pendiri bangsa sejak Indonesia merdeka. Hal ini tercantum dalam Pembukaan UUD 1945 yang berbunyi ikut mencerdaskan kehidupan bangsa berdasarkan Pancasila. ${ }^{25}$ Akantetapi sekitar tahun 1970an pendidikan budi pekerti mulai tergerus bahkan sampai dihilangkan. Akibat dari ketiadaan budi pekerti, Indonesia harus menanggung konsekuensinya berupa bermacammacam kasus KKN (Korupsi, kolusi, dan Nepotisme). Sehingga masyarakat mulai menuntut untuk mengembalikan pendidikan budi pekerti yang sudah terlupakan.

Setelah melalui perdebatan panjang antara pihak Diknas dan Kemenag, akhirnya sejak tahun 1975 pendidikan budi pekerti diintregasikan ke dalam mata pelajaran Pendidikan kewarganegaraan (Civics), yang kemudian menjadi mata pelajaran Pendidikan Moral Pancasila (PMP). Dalam kurikulum 1984, Moral pancasila diintregasikan ke dalam empat mata pelajaran, yaitu PMP, Pendidikan Pendidikan Sejarah Perjuangan Bangsa (PSPB), P4 dan Sejarah Nasional. Dalam kurikulum 1994 pelajaran ini tercakup dalam mata pelajaran Pendidikan Pancasila dan Kewarganegaraan (PPKn). Dan pada kurikulum terakhir tercakup dalam mata pelajaran Pendidikan Kewarganegaraan (PKn). ${ }^{26}$

Kemudian akibat berbagai macam tuntutan, pendidikan budi pekerti pun dicanangkan pada tahun 1994 melalui kurikulum. Sudah semestinya nilai-nilai budi pekerti diajarkan di sekolah agar generasi muda mampu berperilaku sesuai dengan moral yang diharapkan menuju terwujudnya manusia Indonesia seutuhnya yang bermoral, berkarakter, berakhlak mulia dan berbudi pekerti luhur sesuai dengan tujuan pembangunan manusia Indonesia yang kemudian dicanangkan ke dalam tujuan pendidikan nasional. ${ }^{27} \mathrm{Hal}$ tersebut senada dengan yang dianjurkan oleh Ki Hajar Dewantara agar kita tetap memperhatikan ilmu jiwa, ilmu jasmani, ilmu keadaban dan kesopanan (etika dan moral), ilmu estetika, dan menerapkan cara-cara pendidikan yang membangun karakter. ${ }^{28}$

Dasar-dasar pendidikan barat dirasakan Ki Hadjar tidak tepat dan tidak cocok untuk mendidik generasi muda Indonesia karena pendidikan barat bersifat regering, tucht, orde (perintah, hukuman dan ketertiban). Karakter pendidikan semacam ini dalam prakteknya merupakan suatu perkosaan atas kehidupan batin anak-anak. Akibatnya, anak-anak rusak budipekertinya karena selalu hidup di bawah paksaan/tekanan. Menurut Ki Hadjar, cara mendidik semacam itu tidak akan bisa membentuk seseorang hingga memiliki "kepribadian". Masih menurut Ki Hadjar Dewantara pendidikan adalah daya-upaya untuk memajukan bertumbuhnya budi pekerti (kekuatan batin, karakter), pikiran (intelek) dan tubuh anak, dalam rangka kesempurnaan hidup dan keselarasan dengan dunianya. ${ }^{29}$

\footnotetext{
${ }^{24}$ Paul Suparno, dkk, Pendidikan Budi Pekerti di Sekolah: Suatu Tinjauan Umum, ( Yogyakarta: Kanisius, 2002), hlm., 13-18

${ }^{25}$ UUD '45, Sistem Pendidikan Nasional, (?: ?, 2008), hlm,. 1.

${ }^{26}$ May Muflihah Ar Rozi, "Pemikiran Ki Hajar Dewantara Tentang Konsep Pendidikan Budi Pekerti",

(Skripsi, STAIN Salatiga, Salatiga, 2013), hlm.,62.

${ }^{27}$ Ibid, hlm., 12.

${ }^{28} \mathrm{Ki}$ Hajar, hlm,. 89.

${ }^{29}$ Bartolomeus Samho dan Oscar Yasunari, "Konsep Pendidikan Ki Hajar Dewantara dan TantanganTantangan Implementasinya di Indonesia Dewasa Ini”, hlm., 28.
} 
Pertama, manusia Indonesia yang berbudi pekerti ialah yang memiliki kekuatan bathin dan karakter dimana pendidikan mengarah pada peningkatan citra manusia Indonesia yang berpendirian teguh serta berpihak pada nilai-nilai kebenaran.

Kedua, manusia Indonesia yang maju pikirannya. Ini yang disebut kecerdasan secara kognitif. Manusia Indonesia yang cerdas secara intelektual akan terbebas dari pembodohan.

Ketiga, manusia Indonesia yang maju dalam tataran fisik atau tubuh. Tentunya dalam hal ini tidak hanya sehat secara jasmani akantetapi penegtahuan yang benar dalam memerdekakan diri dari berbagai dorongan kearah tindak kejahatan. Pikiran yang maju dan budi pekerti yang maju memperoleh dukungan untuk mendeklarasi kemerdekaan diri dari segala bentuk penindasan ego diri yang pongah dan serakah serta memiliki kemampuan untuk menegaskan eksistensi diri secara beradab sebagai manusia yang merdeka secara jasmani dan ruhani.

Dalam konteks penalaran mengenai konsep pendidikan Ki Hajar diatas dapat dikonklusikan bahwa pendidikan merupakan upaya pemanusiaan manusia secara manusiawi, utuh, dan mengarah pada kemerdekaan lahiriyah dan bathiniyah. sehingga pendidikan harus bersentuhan dengan upaya-upaya konkret berupa pengajaran dan pendidikan. Sejalan dengan tujuan pendidikan Ki Hajar Dewantara, Undang-undang No. 20 Tahun 2003 tentang sistem pendidikan nasional menyatakan pendidikan nasional bertujuan untuk mengembangkan potensi peserta didik agar menjadi manusia yang beriman dan bertakwa kepada Tuhan yang maha esa, berakhlak mulia, sehat, berilmu, cakap, kreatif, mandiri, dan menjadi warga negara yang demokratis serta bertanggung jawab. ${ }^{30}$

Cakupan pendidikan karakter meliputi aspek kognitif, afektif, dan perilaku moral yang dialami individu, baik sebagai individu maupun warga negara yang baik. Oleh karena itu, sekolah bertanggung jawab untuk memberikan bantuan terhadap anak didik dalam menguasai moralitas dan kebangsaan sehingga menjadi warga Negara yang baik. ${ }^{31}$ Tentunya pernyataan ini linier dengan pendapat Ki Hajar Dewantara bahwa keseimbangan unsure cipta, rasa dan karsa yang tidak dapat dipisah-pisahkan ini memperlihatkan bahwa Ki Hajar Dewantara tidak memandang pendidikan hanya sebagai proses penulasan atau transfer ilmu pengetahuan (transfer of knowladge) saja. Hal ini sesuai dengan kondisi yang dihadapi oleh Ki Hajar Dewantara bahwa pendidikan pada masa itu (kolonial Belanda) penuh dengan semangat keduniawian (materialism), penalaran (intellektualism) serta individualism. ${ }^{32}$

Berikut merupakan landasan-landasan dalam menerapkan dan mengembangkan pendidikan karakter di Indonesia, diantaranya: Agama, Pancasila, Budaya, Tujuan Pendidikan Nasional. ${ }^{33}$

Ada tiga unsur penting yang perlu diperhatikan dalam menanamkan nilai moral diantaranya unsur pengertian, perasaan, dan tindakan moral. Ketiga unsur ini saling berkaitan. Ketiga unsur ini perlu diperhatikan supaya nilai yang kita tanamkan tidak tinggal sebagai pengetahuan saja, tetapi sunguh menjadi tindakan nyata. Unsur pengertian moral menyangkut peserta didik dibantu untuk mengerti apa isi nilai yang digeluti dan mengapa nilai itu harus dilakukan dalam kehidupan mereka. ${ }^{34}$ Sejalan dengan konsep pendidikan budi pekerti Ki Hajar Dewantara bahwa budi pekerti berarti pikiran, perasaan, dan

\footnotetext{
${ }^{30}$ Undang-Undang Nomor 20 Tahun 2003 tentang Sistem Pendidikan Nasional, (Jakarta: Arta Duta Mas, 1994), hlm., 33.

${ }^{31}$ Thomas Lickona, Educating for Character:Bagaimana Sekolah dapat Mengajarkan Sikap Hormat dan

Tanggung Jawab, Edisi 1, hlm., 14.

${ }^{32}$ Ki Hajar, hlm,. 139.

${ }^{33}$ Muhammad Fadillah dan Lilif Maulifatu Khorida, Pendidikan Karakter AUD, (Jogyakarta: Ar-Ruzz Media, 2013)., hlm, 33-34.

34 Thomas Lickona, 84
} 
kemauan. Budi pekerti merupakan sifat jiwa, dari angan-angan sampai terjelma menjadi tenaga.

Tiga unsur tersebut tertuang dalam tiga macam metode pengajaran budi pekerti yang dikembangkan oleh KI Hajar Dewantara diantaranya: Metode Ngerti, memberikan pemahaman sebanyak-banyaknya terhadap peserta didik. Didalam pendidikan budi pekerti, seorang guru dan orang tua wajib menanamkan pemahaman tentang tingkah-laku yang baik, sopan-santun dan tata krama yang baik kepada peserta didiknya agar mereka mengetahui. Pemahaman ini mengandung harapan agar peserta didik mengetahui nilai-nilai kebaikan dan dapat memahami maksud serta akibat dari tingkah laku yang buruk yang dapat merugikan diri sendiri dan orang lain serta membawa penyesalan dikemudian hari. Selain itu seorang guru juga memiliki tugas untuk memberikan pengertian kepada peserta didik tentang hakikat hidup bermsyarakat, beragama, berbangsa dan bernegara agar peserta didik mampu menjadi manusia yang merdeka dan memahami pengetahuan tentang perilaku baik dan buruk serta memliki budi pekerti yang luhur.

Metode Ngrasa. Maksud dari metode ini adalah berusaha semaksimal mungkin memahami dan merasakan tentang pengetahuan yang diperolehnya. Dalam hal ini peserta didik akan dididik untuk dapt memperhitungkan dan membedakan antara yang benar dan yang salah. ${ }^{35}$

Metode Nglakoni. Ki Hajar Dewantara menjadikan metode ini sebagai tahapan pamungkas dalam metode pengajaran budi pekerti. Maksud dari metode nglakoni adalah mengerjakan setiap tindakan, bertanggung jawab serta memikirkan dari tindakan berdasarkan pengetahuan yang didapat. Sebuah pemahaman akan tertuang dalam bentuk tindakan jika dirasa tidak mengganggu hak orang lain, tidak menyakiti orang lain maka dia harus melakukan tindakan tersebut. Dari ketiga tahapan metode tersebut, tidak terlalu jika penulis menyimpulkan bahwa metode ini menekankan pada penyadaran diri peserta didik.

Analisis di atas menjadikan pendidikan di Indonesia mengkaji dan membangkitkan pendidikan moral atau pendidikan budi pekerti atau pendidikan karakter. Hal ini bukan hanya dirasakan oleh bangsa dan masyarakat Indonesia saja sebenarnya, akan tetapi juga oleh negara-negara maju. Bahkan di negara-negara Industri dimana ikatan moral menjadi semakin longgar, masyarakatnya mulai merasakan perlunya revival dari pendidikan moral yang pada akhir-akhir ini mulai di telantarkan. ${ }^{36}$

Dalam perkembangan selanjutnya, berkaitan dengan krisis ekonomi dan politik Indonesia yang juga memicu peninjauan ulang terhadap pendidikan nasional, maka perdebatan tentang pendidikan budi pekerti kembali menjadi wacana publik. Akan tetapi, hasil perumusan Depdiknas tahun 2000 dan Depag tahun 2000 menyimpulkan bahwa pendidikan budi pekerti bukan menjadi pelajaran tersendiri (monolitik), tetapi merupakan program pendidikanterpadu yang memerlukan perilaku, keteladanan, pembiasaan, bimbingan dan penciptaan lingkungan yang kondusif. Dengan demikian pendidikan budi pekerti diintregasikan ke dalam semua mata pelajaran dan program pendidikan, seperti pendidikan agama dan PPKn. ${ }^{37}$

Pendidikan nasional menurut paham Ki Hadjar Dewantara, seperti yang diterapkannya dalam Taman Siswa, ialah pendidikan yang beralaskan garis-hidup dari bangsa (kultur nasional) dan ditujukan untuk keperluan perikehidupan yang bisa mengangkat derajat negara dan rakyat. Orientasi globalnya adalah agar rakyat Indonesia dapat bekerja bersama-sama dengan bangsa-bangsa yang lain untuk kemuliaan manusia di seluruh dunia. Dalam rangka itu, Ki Hadjar Dewantara mengedepankan tiga ajaran tentang

\footnotetext{
${ }^{35}$ May Muflihah Ar Rozi, "Pemikiran Ki Hajar Dewantara Tentang Konsep Pendidikan Budi Pekerti", (Skripsi, STAIN Salatiga, Salatiga, 2013), hlm.,55.

${ }^{36}$ Nurul Zuriah, Pendidikan Moral dan Budi Pekerti Dalam Prespektif Perubahan, (Jakarta :PT Bumi Aksara, 2007), hml., 10.

${ }^{37}$ Zuriah, Pendidikan Moral, hlm., 118.
} 
pendidikan (tiga fatwa), yakni: Tetep, antep dan mantep; ngandel, kandel, kendel dan bandel; Neng, ning, nung dan nang; 38

Berangkat dari keyakinan akan nilai-nilai tradisional itu, Ki Hadjar yakin pendidikan yang khas Indonesia haruslah berdasarkan citra nilai Indonesia juga. Maka ia menerapkan tiga semboyan pendidikan yang menunjukkan kekhasan Indonesia, yakni : Pertama, Ing Ngarsa Sung Tuladha, artinya seorang guru adalah pendidik yang harus memberi teladan. Ia pantas digugu dan ditiru dalam perkataan dan perbuatannya. Kedua, Ing Madya Mangun Karsa, artinya seorang guru adalah pendidik yang selalu berada di tengah-tengah para muridnya dan terus-menerus membangun semangat dan ide-ide mereka untuk berkarya. Ketiga, Tut Wuri Handayani, artinya seorang guru adalah pendidik yang terus-menerus menuntun, menopang dan menunjuk arah yang benar bagi hidup dan karya anak-anak didiknya.

Senada dengan semboyan pendidikan di atas adalah metode pendidikan yang dikembangkan, yang sepadan dengan makna "paedagogik", yakni Momong, Among dan Ngemong, yang berarti bahwa pendidikan itu bersifat mengasuh. Mendidik adalah mengasuh anak dalam dunia nilai-nilai. Praksis pendidikan dalam perspektif ini memang mementingkan ketertiban, tapi pelaksanaannya bertolak dari upaya membangun kesadaran, bukan berdasarkan paksaan yang bersifat "hukuman". Maka, pembagian usia 07, 7-14, dan 14-21 dalam proses pendidikan yang digagas Ki Hadjar Dewantara bukan tanpa landasan pedagogik. ${ }^{39}$

Pembagian demikian berdasarkan fase-fase di mana masing-masing menuntut peran pendidik dengan isi dan nilai yang berbeda-beda. Metode Ngemong, Momong, Among dan semboyan Ing ngarso sung tulodho, Ing Madya mangun karsa, dan Tut wuri handayani bukan berasal dari sebuah pemikiran Ki Hadjar Dewantara yang terpisah. Pendidikan bukan hanya masalah bagaimana membangun isi (kognisi) namun juga pekerti (afeksi) anak-anak Indonesia, yang tentunnya diharapkan "meng-Indonesia" agar mereka kelak mampu menjadi pemimpin-pemimpin bangsa yang "meng-Indonesia" (memiliki kekhasan Indonesia).

Perlu diketahui bahwa desain pembelajaran budi pekerti semestinya tidak muncul sebagai suatu mata pelajaran atau tidak diatasnamakan mata pelajaran budi pekerti. Namun, aplikasi nilai-nilai budi pekerti itu terserap sebagai muatan di setiap aktivitas pembelajaran yang sudah dirancang. Dengan demikian, setiap mata pelajaran dapat bermuatan nilai-nilai budi pekerti. Oleh karena itu, pendidikan karakter untuk mengembangkan nilai budi pekerti ini tentu saja tidak dapat berhasil dalam waktu yang singkat. Misalnya, langsung dapat dilihat melalui bentuk spot mata pelajaran di awal, di tengah, ataupun di akhir saja. Di samping itu, juga jangan diharapkan langsung dapat berhasil dalam satu mata pelajaran. Pendidikan karakter yang hanya menekankan pada satu atau dua mata pelajaran saja tidak akan dapat menjamin tercapainya karakter peserta didik yang diinginkan.

\section{Hubungan Konsep Pendidikan Budi Pekerti Ki Hajar Dewantara dengan Pendidikan Agama Islam}

Mengingat bahwa Ki Hajar Dewantara merupakan keturunan Sri Paku Alam atau sering kita kenal Sunan Kalijaga, maka secara tersirat setiap konsep yang dirancang oleh pemikiran beliau tidak akan keluar dari nilai-nilai Ke-islam-an. Beliau juga seorang tokoh yang sedari kecil hidup didalam kultur religiuitas yang tinggi. Sehingga penulis mencoba

\footnotetext{
${ }^{38}$ Bartolomeus Samho dan Oscar Yasunari, "Konsep Pendidikan Ki Hajar Dewantara dan TantanganTantangan Implementasinya di Indonesia Dewasa Ini”, hlm., 34.

${ }^{39}$ Bartolomeus Samho dan Oscar Yasunari, "Konsep Pendidikan Ki Hajar Dewantara dan TantanganTantangan Implementasinya di Indonesia Dewasa Ini”, hlm., 45.
} 
menghubungkan antara Pendidikan Agama Islam dengan Konsep Pendidikan Budi Pekerti Ki Hajar Dewantara.

Pendidikan Agama Islam merupakan usaha sadar dan terencana untuk menyiapkan siswa dalam meyakini, memahami, menghayati, dan mengamalkan ajaran Islam melalui kegiatan bimbingan pengajaran dan latihan. ${ }^{40}$ Pendidikan Agama Islam merupakan salah satu pelajaran yang yang memiliki peran yang amat strategis dalam memberikan pembuinaan dan bimbingan sikap kepribadian siswa di tengah dekadensi moral dewasa ini.

Pendidikan Agama Islam sebagai suatu proses pengembangan potensi kreatifitas peserta didik, bertujuan untuk mewujudkan manusia yang beriman dan bertakwa kepada Allah SWT terampil, memiliki etos kerja yang tinggi berbudi pekerti luhur, mandiri dan bertanggung jawab terhadap dirinya, bangsa, dan negara serta agama.

Pendidikan Agama Islam mempunyai andil yang sangat besar dalam mewujudkan sebagian dari tujuan pendidikan nasional pasal 2 dan 3 Undang-undang Sistem Pendidikan Nasional yang berbunyi:

"Pendidikan Nasional berdasarkan pancasila dan Undang-Undang Dasar Negara Republik Indonesia 1945. Pendidikan Nasional befungsi mengembangkan kemampuan dan membentuk watak dan peradapan bangsa yang bermanfaat dalam rangka mencerdaskan kehidupan bangsa, bertujuan untuk mengembangkan potensi pesrta didik agar menjadi manusia beriman dan bertaqwa kepada Tuhan yang Maha Esa, berakhlak mulia, sehat, berilmu, cakap, kreatif, mandiri, dan menjadi warga Negara yang demokratis serta bertanggng jawab." 41

Berdasarkan uraian diatas bahwa sebenarnya secara tersirat pendidikan Akhlak atau budi pekerti merupakan suatu hal yang sangat penting dalam kehidupan islami. Pendidikan budi pekerti merupakan asset seseorang dalam berinteraksi dengan sesamanya, budi pekerti juga mengatur hubungan manusia dengan segala yang ada dalam kehidupan ini, ia juga mengatur hubungan manusia dengan Sang Kholik.

"Akhlak" dalam Kamus Besar Bahasa Indonesia hanya diartikan budi pekerti dan kelakuan. Namun pada dasarnya akhlak mempunyai makna yang lebih dari sekedar budi pekerti atau kelakuan. ${ }^{42}$ Karena akhlak memiliki hubungan khusus dengan sang Kholiq, sesama manusia, dan alam semesta. Secara implicit aklak juga merupakan tabiat dimana tabiat itu sendiri memiliki arti khusus dalam Islam yang berarti citra batin suatu individu yang menetap. Bentuk citra ini terdapat pada konstitusi individu yang Allah SWT ciptakan. Tabiat juga merupakan daya dari nafs kulliyah yang berfungsi dalam menggerakkan jasad manusia. 43

Pendidikan Agama Islam (PAI) dan Budi Pekerti merupakan pendidikan yang secara mendasar menumbuhkembangkan akhlak peserta didik melalui pembiasaan dan pengamalan ajaran Islam secara menyeluruh (kaffah). PAI dan Budi Pekerti berlandaskan pada aqidah Islam yang berisi tentang keesaan Allah Swt. sebagai sumber utama nilai-nilai kehidupan bagi manusia dan alam semesta. Sumber lainnya adalah akhlak yang merupakan manifestasi dari aqidah, yang sekaligus merupakan landasan pengembangan nilai-nilai karakter bangsa Indonesia. Dengan demikian, Pendidikan Agama Islam dan Budi Pekerti

\footnotetext{
${ }^{40}$ Depertemen Agama RI, Pedoman Umum Pendidikan Agama Islam, sekolah Umum dan Dasar, (Jakarta: Direktorat Madrasah dan Pendidikan Agama, Tth)., 3.

${ }^{41}$ UUD RI Nomor 20 Tahun 2003, Tentang Sistem Pendidikan Nasional, (Jakarta: Media Wacana Press, 2003), hlm., 9.

${ }^{42}$ Evi Hanifah, Istilah Nilai, karakter, Akhlak, Moral, Budi Pekerti, dan Etika, diakses dari https://hanivie.wordpress.com/2013/05/17/istilah-nilai-karakter-akhak-moral-budi-pekerti-dan-etika/ pada tanggal 07 Mei 2017 pukul 22.40

${ }^{43} \mathrm{http} / / /$ www.definisimenurutparaahli.com/pengertian-tabiat/ pada tanggal 07 Mei 2017 pukul 10.49
} 
merupakan pendidikan yang ditujukan untuk dapat menserasikan, menselaraskan dan menyeimbangkan antara iman, Islam, dan ihsan yang diwujudkan dalam :

1. Membentuk manusia Indonesia yang beriman dan bertakwa kepada Allah Swt. serta berakhlak mulia dan berbudi pekerti luhur (Hubungan manusia dengan Allah Swt).

2. Menghargai, menghormati dan mengembangkan potensi diri yang berlandaskan pada nilai-nilai keimanan dan ketakwaan (Hubungan manusia dengan diri sendiri)

3. Menjaga kedamaian dan kerukunan hubungan inter dan antar umat beragama serta menumbuhkembangkan akhlak mulia dan budi pekerti luhur (Hubungan manusia dengan sesama)

4. Penyesuaian mental keislaman terhadap lingkungan fisik dan social (Hubungan manusia dengan lingkungan alam).

Berdasarkan pada prinsip di atas, PAI dan Budi Pekerti dikembangkan dengan memperhatikan nilai-nilai Islam rahmatan lilalamin yang mengedepankan prinsip-prinsip Islam yang humanis, toleran, demokratis, dan multikultural.

Menurut Ajaran Islam,hakikat pendidikan adalah menegembalikan nilai-nilai pada manusia (fitrah) dengan membimbing Al-Qur'an dan As-Sunnah (hadist) sehingga menjadi manusia yang berakhlak mulia (insan kamil). ${ }^{4}$

Sejalan dengan menghilangnya mata pelajaran budi pekerti masalah bangsa yang kian kompleks juga memunculkan masalah akhlak dan moral di kalangan peserta didik pada berbagai level atau tingkatan. Sekali lagi, pikiran dan logika yang sedikit simplisit menganggap masalah ini disebabkan lenyapnya pendidikan budi pekerti dan kegagalan Pendidikan Agama Islam.

Berbagai usulan tentang perlunya pendidikan budi pekerti dalam pembangunan karakter dan pembentukan moralitas bangsa, bukanlah suatu hal yang baru. Sebagaimana pendapat Azyumardi Azra tahun 2000 yang disampaikan oleh Nurul Zuhriah bahkan sebelum pelajaran agama menjadi mata pelajaran wajib, dalam rencana pelajaran pada tahub 1947, yang ada hanyalah mata pelajaran "didikan budi pekerti" yang bersumber dari nilai-nilai traditional, khususnya yang terdapat dalam cerita pewayangan. ${ }^{45}$

Budi pekerti atau karakter yang dalam bahasa Agama disebut Akhlak adalah suatu istilah yang merujuk pada kebaikan, moralitas dan perilaku yang baik. ${ }^{46}$ budi pekerti juga merupakan perpaduan dari hasil rasio dan rasa yang bermanifestasi pada karsa dan tingkah laku manusia. ${ }^{4}$

Pendidikan akhlaq adalah suatu proses pembinaan, penanaman, dan pengajaran, pada manusia dengan tujuan menciptakan dan mensukeskan tujuan tertinggi agama Islam, yaitu kebahagiaan dua kampung (dunia dan akhirat), kesempurnaan jiwa masyarakat, mendapat keridlaan, keamanan, rahmat, dan mendapat kenikmatan yang telah dijanjikan oleh Allah SWT yang berlaku pada orang-orang yang baik dan bertaqwa. ${ }^{48}$

Karena akhlaq merupakan fondasi (dasar) yang utama dalam pembentukan pribadi manusia yang seutuhnya, maka pendidikan yang mengarah terbentuknya pribadi yang berakhlaq, merupakan hal yang pertama yang harus dilakukan, sebab akan melandasi kestabilan kepribadian manusia secara keseluruhan.

Rasulullah SAW bersabda: ${ }^{49}$

عن ابى هريرة رضى الله عنه قال : قال رسول الله صلى الله عليه وسلم: انما بعثت لاتم صا لح الاخلاق (رواه احمد)

\footnotetext{
${ }^{44}$ Anas dan Irwanto, Pendidikan Karakter, (Bandung: Pustaka Setia, 2013)., hlm, 71.

${ }^{45}$ Zuriah, Pendidikan Moral, hlm.,117 .

${ }^{46}$ Muhammad Yaumi, Pendidikan Karakter, Landasan, Pilar, dan Implimentasi, (Jakarta: PrenadaMedia

Group, 2014), hlm., 36.

${ }^{47}$ Rachmat Djatnika, Sistem Ethika Islam: Akhlak Mulia, (Jakarta: Pustaka Panjimas, 1996), hlm., 26.

${ }^{48}$ Omar al-Thaumy al-Syaibany, Falsafah Pendidikan Islam, terj. (Jakarta: Bulan Bintang, 1979), hlm. 346.

49 Muhammad 'Abdussalam 'Abdutsani, Musnad Imam Ahmad bin Hambal, Juz ii, (Libanon : Dar alKutub, tt.), hlm., 504.
} 
Dari Abu Hurairah $r$. a. Rasulullah saw telah bersabda : aku diutus hanyalah untuk menyempurnakan budi pekerti yang luhur (HR. Ahmad).

Dengan memiliki akhlaq yang karimah maka seseorang akan dapat berhubungan dengan baik dengan sang pencipta, dapat diterima dalam setiap pergaulannya, juga melestarikan alam ciptaan Allah, oleh karena itu penanaman akhlaqul karimah perlu ditanamkan sejak dini pada anak.

Unsur-unsur yang ada dalam filsafat pendidikan karakter berbasis agama (Islam) dan budaya bangsa adalah sebagai berikut:

1. System system pendidikan diarahkan pada pendidikan bervisi Agama Islam

2. Tujuan pendidikan karakter, yaitu pembentukan karakter peserta didik yang bervisi agam Islam tapi fleksibel dan berpikiran terbuka, objektif, toleran, moderat, serta berwawasan luas

3. Pelaksanaan pendidikan yang menyangkut metode, teknik, peralatan, dan persoalannya. 50

Dalam konsep Islam, sebagaimana disebutkan oleh Muzayyin Arifin, bahwa hakikat pendidikan ialah usaha orang dewasa Muslim yang bertaqwa secara sadar mengarahkan dan membimbing pertumbuhan serta perkembangan fitrah (kemempuan dasar) anak didik melalui pelajaran Agama Islam kearah titik maksimal pertumbuhan dan perkembangan. ${ }^{51}$

Islam menginginkan akhlaq yang mulia, karena akhlaq yang mulia ini di samping akan membawa kebahagiaan bagi masyarakat pada umumnya. Dengan kata lain bahwa akhlaq utama yang ditampilkan seseorang manfaatnya adalah orang yang bersangkutan. Manfaat tersebut, yaitu:

a. Memperkuat dan menyempurnakan agama

b. Mempermudah perhitungan amal di akhirat

c. Menghilangkan kesulitan

d. Selamat hidup di dunia dan akhirat .52

Pembahasan akhlak menjadi aspek yang sangat penting dalam Pendidikan Agama Islam, karena perubahan hasil belajar bukan hanya aspek pengetahuan atau kognitif saja, melain juga aspek moral, akhlak atau budi pekerti. Dalam pendidikan akhlaq aktualisasi nilai-nilai Islam perlu dipandang sebagai suatu persoalan yang penting dalam usaha penanaman ideologis Islam sebagai pandangan hidup. Namun demikian dalam usaha aktualisasi nilai-nilai moral Islam memerlukan proses yang lama, agar penanaman tersebut bukan sekedar dalam formalitas namun telah masuk dalam dataran praktis. Hal ini memang tidak semudah membalikan telapak tangan, setidaknya Rasulullah SAW memerlukan 13 tahun untuk mengubah Makkah.

Pada kenyataannya, Apabila pembelajaran pendidikan Agama Islam disandingkan dengan budi pekerti maka akan memiliki jalur yang sejalan dan linier. Hal ini disebabkan karena kedua aspek tersebut baik pendidikan agama islam maupun budi pekerti sangat berkaitan erat dengan akhlak siswa. Akhlak yang dimiliki oleh siswa merupakan interpretasi sehari-hari dari indicator khusus ruang lingkup pendidikan agama islam dari bentuk tingkah laku yang dapat dinilai baik dan buruk. Jika kita liat dar indicator pendidikan agama islam diantaranya keimanan, Al-Qur'an/ Hadist, akhlak, fiqh dan sejarah Islam adalah cerminan yang tak terpisahkan dari kepribadian manusia khususnya berkenaan dengan budi pekerti. ${ }^{53}$ Dari uraian diatas secara tersirat penulis menyimpulkan bahwa ada hubungan yang signifikan antara Pendidikan Agama Islam dan Budi Pekerti. Karena pada dasarnya Islam menginginkan akhlak yang mulia sehingga Pendidikan Agama

\footnotetext{
${ }^{50}$ Anas dan Irwanto, Pendidikan Karakter, hlm, 213.

${ }^{51}$ Fadillah dan Khorida, Pendidikan Karakter AUD, hlm., 19.

${ }^{52}$ Abu Bakar Atjeh, Filsafat dalam Islam, (Semarang: CV. Ramadhani, 1971), hlm. 173.

${ }^{53}$ Sri Fatmawati, Hubungan Antara Pembelajaran Pendidikan Agama Islam dengan Akhlak Siswa, (Skripsi, Universitas Islam Negeri Syarif Hidayatullah, Jakarta, 2011), hlm., 56.
} 
Islam memegang peranan penting dalam membentuk budi pekerti luhur pada pribadi peserta didik.

\section{Penutup \\ Kesimpulan}

Dalam kapasitasnya sebagai seorang pemikir dan praktisi pendidikan, tidaklah berlebihan kalau Ki Hadjar Dewantara disebut sebagai pejuang kemanusiaan di Indonesia. Ia berupaya membangun dan menyelenggarakan pendidikan untuk manusia di Indonesia dengan konsep, landasan, semboyan dan metode yang menampilkan kekhasan kultural Indonesia. Semuanya itu dilakukannya demi mewujudkan idealism terdalamnya, yakni membangun kesadaran manusia di Indonesia akan hak-haknya.

Berdasarkan paparan di babsebelumnya, kiranya tidak terlalu jauh jika penulis menyimpulkan bahwa Konsep Pendidikan Budi Pekerti Ki Hajar Dewantara dapat diterapkan di Indonesia melalui empat alternatif strategi secara terpadu.

1. Strategi pertama ialah dengan mengintegrasikan konten kurikulum pendidikan budi pekerti yang telah dirumuskan ke dalam seluruh mata pelajaran yang relevan, terutama mata pelajaran agama, kewarganegaraan, dan bahasa (baik bahasa Indonesia maupun bahasa daerah).

2. Strategi kedua ialah dengan mengintegrasikan pendidikan budi pekerti ke dalam kegiatan sehari-hari di sekolah.

3. Strategi ketiga ialah dengan mengintegrasikan pendidikan budi pekerti ke dalam kegiatan yang diprogramkan atau direncanakan.

4. Strategi keempat ialah dengan membangun komunikasi dan kerjasama antara sekolah, orang tua dan masyarakat.

Disamping itu, Pembelajaran Pendidikan Islam dengan budi pekerti sangat berkaitan erat dalam membentuk akhlak yang mulia terhadap peserta didik. Hendaknya penyelenggaraan pendidikan jangan terjebak pada pencapaian target sempit, yang hanya melakukan transfer of knowledge melainkan perlu dengan sengaja (by design) mengupayakan terjadinya transformasi nilai budi luhur dalam membentuk karakter anak bangsa. Oleh karena itu, Pendidikan Agama Islam memiliki andil yang besar dalam pembentukan karakter peserta didik. Secara tersirat hasil penelitian ini menjelaskan bahwa Konsep pendidikan budi pekerti menurut pandangan Ki Hadjar Dewantara patut kita jadikan sebagai acuan dalam pengembangan pendidikan karakter. Pendidikan karakter harus bercorak nasional dengan menerapkan cara-cara; pemberian contoh, pembiasaan, laku, dan pengalaman lahir-batin.

Saran

\section{Bagi Pemerintah}

a. Diharapkan dalam pembuatan atau perubahan kurikulum harus tetap mengedepankan karakter sebagai tujuan akhir dari Pembelajaran. Kebijakan boleh berubah, kurikulum boleh berganti, namun budi pekerti luhur siswa harus menjadi prioritas utama dalam pendidikan. Karena hal tersebut merupakan fondasi awal untuk keberlangsungan bangsa.

b. Hendaknya pemerintah memisahkan ranah pendidikan dengan aspek politik, sehingga segala bentuk kebijakan yang berkaitan dengan pendidikan tidak ditunggangi oleh kepentingan-kepentingan sesaat. 


\section{Bagi Pendidik}

a. Diharapkan dalam proses pembelajaran pendidik memberikan pengetahuan bagi peserta didik tentang segala hal yang berhubungan dengan kemampuan yang ada dalam diri termasuk Pendidikan Agama Islam.

b. Hendaknya pendidik menjadi suri teladan yang baik bagi para peserta didiknya. Sehingga menjadi seorang figur yang tepat yang dapat mencerminkan akhlak yang baik serta menjadi pemimpin yang amanah.

\section{Bagi Siswa}

a. Keberhasilan dan kesuksesan dalam hidup tak dapat terpisahkan dari anggapan seseoramng tentang kita. Apabila akhlak yang kita cerminkan adalah akhlak yang tidak baik maka masyarakat dapat menilai secara menyeluruh dan akan berimbas pada keberhasilan yang kita peroleh.

b. Jagalah akhlak dalam bergaul di masyarakat serta biasakan berperilaku akhlakul karimah dan mengikuti sunnah Rosul

\section{Daftar Pustaka}

Abuddin, Nata. Tokoh-tokoh Pembaruan Pendidikan Islam di Indonesia. Jakarta: Raja Grafindo Persada. 2005.

Ahmadi, Rulam. Penganar Pendidikan. Yogyakarta: Ar Ruzz Media. 2015.

al-Syaibany, Omar al-Thaumy. Falsafah Pendidikan Islam. terj. Jakarta: Bulan Bintang. 1979.

Ar Rozi, May Muflihah. "Pemikiran Ki Hajar Dewantara Tentang Konsep Pendidikan Budi Pekerti”. Skripsi, STAIN Salatiga, 2013.

Arikunto, Suharsimi. Prosedur Penelitian. Jakarta: PT Renika Cipta. 2013. Arta Duta Mas. 1994.

Atjeh, Abu Bakar. Filsafat dalam Islam. Semarang: CV. Ramadhani. 1971.

Bariroh Siti yang berjudul Pendidikan Budi Pekerti (Studi Komparasi Ki Hadjar Dewantara dan Muhammad Athiyal Al abrasyi) Skripsi. Jurusan Kependidikan Islam Fakultas Ilmu Tarbiyah dan Keguruan Universitas Islam Sunan Kalijaga Yogyakarta 2014.

Depertemen Agama RI. Pedoman Umum Pendidikan Agama Islam, sekolah Umum dan Dasar. Jakarta: Direktorat Madrasah dan Pendidikan Agama. Tth.

Dewantara Ki Hadjar, Bagian Pertama Pendidikan. Yogyakarta: Majelis Luhur Persatuan Taman Siswa. 1977.

Djatnika, Rachmat. Sistem Ethika Islam:Akhlak Mulia. Jakarta: Pustaka Panjimas. 1996.

Dyah, Upik. Ki Hadjar Dewantar Bapak Pendidikan Indonesia. Yogyakarta: Arti bu intaran. 2012.

Fadillah, Muhammad dan Lilif Maulifatu Khorida. Pendidikan Karakter AUD. Jogyakarta: ArRuzz Media. 2013. 
Fathorrohman, Pupuh dkk. Pengembangan Pendidikan Karakter. Bandung : PT Refika Aditama. 2013.

Hanifah, Evi. Istilah Nilai, karakter, Akhlak, Moral, Budi Pekerti, dan Etika, diakses dari https://hanivie.wordpress.com/2013/05/17/istilah-nilai-karakter-akhak-moralbudi-pekerti-dan-etika/ pada tanggal 07 Mei 2017 pukul 24.23

Haryanto. Pendidikan Karakter Menurut Ki Hadjar Dewantara. Kurikulum dan Teknologi Pendidikan FIP UNY, t.p, t.t.

Hasbullah. Dasar-dasar- Ilmu Pendidikan. Jakarta: PT Rajagrafindo Persada. 2009.

Hidayatullah, Furqon. Pendidikan Karakter Membangun Peradaban Bangsa, Surakarta: Yuma Pressindo. 2007.

http://www.definisimenurutparaahli.com/pengertian-tabiat/ pada tanggal 07 Mei 2017 pukul 10.49 .

Ihsan, Fuad. Dasar-dasar Kependidikan. Jakarta: PT Rineka Cipta. 2002.

Ihsan, Hamdani. Filsafat Pendidikan Isalam. Bandung: CV Pustaka Setia. 2007.

Jalaluddin dkk. Filsafa Pendidikan. Jakarta: Gaya Media Pratama. 2002.

KBBI (Kamus Besar Bahasa Indonesia) versi offline, edeisi III, data mengacu pada http://pusatbahasa.diknas.go.id/kbbi/

Kementerian Pendidikan Nasional. Kerangka Acuan Pendidikan Karakter Tahun Anggaran 2010. Jakarta: Dirjen Pendidikan Tinggi 2010.

Kosim, Mohammad. Pengantar Ilmu Pendidikan. Surabaya: Pena Salsabila. 2013.

Lickona, Thomas. Educating for Character:Bagaimana Sekolah dapat Mengajarkan Sikap Hormat dan Tanggung Jawab, Edisi 1. Jakarta: Bumi Aksara, 2012.

Maryati, Konsep Pendidikan Budi Pekerti Menurut Ki Hadjar Dewantara dan Relefansinya Dengan Pendidikan Akhlak Dalam Islam, Skripsi, Jurusan Pendidikan Agama Islam Fakultas Ilmu Tarbiyah dan Keguruan UIN Sunan Kalijaga Yogyakarta, 2011,

Mudyaharjo, Redja. Pengantar Pendidikan. Jakarta: PT Rajagrafindo Persada. 2014.

Mulyasa. Manajemen Pendidikan Karakter. Jakarta: PT Bumi Putra. 2014.

Saidah Robiyah yang berjudul konsep Pendidikan Islam Menurut Muhammad Athiyah Alabrsyi dan Relevansinya Dalam Pendidikan Moral Di Indonesia, Skripsi. Jurusan Kependidikan Islam Fakultas Tarbiyah dan Keguruan UN Sunan Kalijaga Yogyakarta 2010.

Salahudin, Anas. Irwanto. Pendidikan Karakter (pendidikan berbasis agama dan budaya bangsa). Bandung: CV Pustaka Setia. 2013.

Samani, Muchlas dan Hariyanto. Konsep dan Model Pendidikan Karakter. Bandung: PT Remaja Rosdakarya. 2011.

Saptono, Dimensi-dimensi Pendidikan Karakter. Jakarta: Erlangga Group. 2011.

Saptono. Dimensi-Dimensi Pendidikan Karakter, Wawasa, Stragtegi, dan Langkah Praktis. Surabaya: Erlangga. 2011.

Soeratman , Darsiti. Ki Hadjar Dewantara. Jakarta: Departemen Pendidikan dan Kebudayaan, 1985.

Suherman, Ema yang berjudul Pendidikan Budi Pekerti Dalam Seat Wedhatama (Studi Analisis Prespektif Pendidikan Agama Islam), Skripsi, Jurusan Pendidikan Agama islam Fakulas Tarbiyah IAIN Sunan Kalijaga Yogyakarta 2003

Sukitman, Tri. Bimbingan Konseling Berbasis Pendidikan Karakter. Yogyakarta: DIVA Press, 2015.

Suparno, Paul dkk. Pendidikan Budi Pekerti di Sekolah: Suatu Tinjauan Umum. Yogyakarta: Kanisius. 2002.

Sutiyono. "Penerapan Pendidikan Budi Pekerti sebagai Pembentukan Karakter Siswa di Sekolah: Sebuah Fenomena dan Realitas." Jurnal Pendidikan Karakter,3 .Oktober, 2013. 
Takdir, Ilahi Muhammad. Gagalnya pendidikan karakter: analisis dan solusi pengendalian karakter emas anak didik. Yogyakarta: Ar Ruzz Media. 2014.

Ulfa, Mariya yang berjudul Konsep Pendidikan Karakter (Studi Komparatif pemikiran Syed Muhammad Naquib Al-attas dan Ki Hadjar Dewantara), Sripsi. Jurusan Kependidikan Islam Fakultas Tarbiyah dan Keguruan UIN Sunan Kalijaga Yogyakarta 2012.

Undang-Undang Nomor 20 Tahun 2003 tentang Sistem Pendidikan Nasional. Jakarta: 2013.

UUD '45. Sistem Pendidikan Nasional. tp: 2008.

UUD RI Nomor 20 Tahun 2003. Tentang Sistem Pendidikan Nasional. Jakarta: Media Wacana Press. 2003.

Yaumi, Muhammad. Pendidikan Karakter, Landasan, Pilar, dan Implimentasi. Jakarta: Prenada Media Group. 2014.

Zuriah Nurul, Pendidikan Moral dan Budi Pekerti Dalam Prespektif Perubahan, (Jakarta :PT Bumi Aksara, 2007), 